\title{
Towards Intrinsic Leadership: A Conceptual Review
}

\author{
Hening Riyadiningsih ${ }^{1}$, Siti Nurhayati, and Haryadi $^{3}$ \\ \{heningriyadiningsih@yahoo.co.id ${ }^{1,}$ nurhayati.ms99@gmail.com², haryadi@gmail.com ${ }^{3}$ \} \\ Jenderal Soedirman University, Purwokerto ${ }^{1}$; Pekalongan University, Pekalongan ${ }^{2}$; Jenderal Soedirman \\ University, Purwokerto ${ }^{3}$
}

\begin{abstract}
Intrinsic leadership is developed based on holistic leadership philosophy where leaders should integrate physical, mind, heart (feelings and emotions), and spirituality. Leaders are able to integrate abilities of analytical, conceptual, emotional, and spiritual in their leadership processes. The purpose of intrinsic leadership to create a vision and value congruence, empowered teamwork among all stakeholders and primarily build an organization like a family so as to create engagement, trust, motivation and certainly have an impact on organization performance. Intrinsic leadership is a development of the concept of authentic leadership and it's developed based on self-concept, spirituality, cognitive evaluation theory, self-teleonomic theory, and eudaemonic identity theory. Conceptually intrinsic leadership differs from previous leadership concepts which only rely on one or some of elements that leaders have as human beings. Intrinsic leadership integrates dimensions of cognitive, affective, conative, and spiritual of leaders in carrying out their leadership functions and roles. Finally, the process of organizational development and transformation through intrinsic leadership is also discussed in this paper.
\end{abstract}

Keywords: intrinsic leadership, authentic leadership, spirituality, self concept, cognitive evaluation theory, self-teleonomic theory, eudaemonic identity theory

\section{Introduction}

Organizations in dealing with changes in the business environment that are fluctuating and unpredictable require the role and function of leaders who are able to encourage subordinate creativity with the aim of being able to survive in a competitive business environment [1]. Changes in social phenomena such as moral degradation, injustice, reduced social solidarity are also considered to be the cause of the emergence of demands for the importance of leaders who are transparent, have an awareness of ethical and moral values, and are able to provide direction to organizations using moral or ethical perspectives [2]. These environmental and social changes also demand the emergence of the need for leaders who are able to create situations of high trust, help employees build on their strengths, become more positive, have broader thinking, add value and feel what is right for their decisions, and the main thing is being able to improve organizational performance [3]. The demands on the needs of leaders with such requirements ultimately require thinking of a different, more comprehensive leadership model that is able to overcome the challenges of the environmental and social changes that occur.

Authentic leadership is developed by experts as a model of leadership that is considered capable of addressing and responding to the demands of the leaders' needs [4] [5] [6] [3]. Based on the analysis of empirical research, authentic leadership have significant influence on organizational outcomes such as commitment [7] [6] [8], job satisfaction [9] [7] [6] [10] [11], OCB or extra effort [6] [10], work happiness and psychological well-being [9] [7] [12], and sustainable performance [6] [13] [14] [15] [16]. Empirically, authentic leadership also reduces 
negative organizational behavior such as stress, burnout, and organizational deviations [8] [13] [17]. Organizational outputs that are positive for organizational life have indicated that authentic leadership is considered a leader behavior pattern that is able to encourage positive psychological capacity of employees [18] [19], positive organizational climate (eg positive ethical climate [20], climate of justice [8], positive work climate [2], building employee confidence in leaders and or supervisors [14], encouraging employee personal identification [21] [22], helping to develop employee moral identity [20]. Thus it can be said that authentic leadership is able to maintain a balance between self-interest and the integrative interests of the organization to optimize outputs for all stakeholders.

Empirical and theoretical authentic leadership modeling related to the measurement dimensions has accommodated cognitive, affective, and conative aspects [23] [24] [25] [7] [26] [6] [14] [21] [2] [15] [27] [8] [28] [29] [30]. Authentic leadership is manifested by the values of honesty, sincerity [25], and represents confidence in realizing their vision and mission based on the values of truth and goodness that exist in themselves [31], contributing to eudaemonic well-being of leaders and followers [25]. Judging from the embodiment of the authentic leadership model actually contained a spiritual dimension. Reffering opinion of Klenke [32] [33] which states that the spiritual component is a determinant of authentic leadership, where he in modeling authentic leadership has integrated contextual, cognitive, affective, conative, and spiritual elements. It's just that in the development and empirical research of authentic leadership has not included the spiritual dimension explicitly as an authentic leadership dimension.

Spirituality as a person's inner life [1] which is applied in the life of his organization can foster creativity and meaningful feelings towards work completion [34] [1]. And when spirituality is applied by the leader in carrying out the duties and functions of his leadership it has spillover effect both vertically and horizontally on the organizational environment [35]. The results of study showed the application of spirituality in the workplace can increase employee creativity [36]; honesty and trust in organizations [37]; meet the personal needs of employees [38]; and can increase employee commitment to goals [39] [40]. Besides these things, the results of the study also showed that spirituality influences job satisfaction [41], organizational citizenship behavior, affective commitment [42] [43], work stress, and performance [35]. The positive impact of spirituality on organizational outputs can be understood because spiritual experience is the basis of every attitude and behavior of organizational members [44]; and able to play a role in controlling the body, mind, emotions, and souls of individuals in the organization [45].

The meaning of authenticity and spirituality refers to constructs related to self [46] [5] [31] [1] [35]. Historical review of the meaning of authenticity and spirituality both philosophically and psychologically basically refers to the question of "who am I" which according to Myer [47] it concern self-concept. Decy \& Ryan states that self-concept is an individual's autonomy needs that are intrinsically sourced [48]. Philosophically, intrinsic means goodness that comes from within oneself which cannot be derived anymore (Aristotle). Functions, tasks and work carried out on the basis of goodness from within oneself (intrinsic) is very likely to propagate both vertically and horizontally in the organization environment, so that positive energy can be reflected from the surrounding environment. The results of research on the effects of authenticity and spirituality applied by leaders show positive energy aura from the organizational environment [9] [7] [12] [1] [49] [50] [51] [52] [53].

Based on thoughts and reviews on the effects of spirituality and authenticity that should be present in leaders inspire the development of leadership models that include the dimension of spirituality and dimensions of authenticity. Intrinsic as a concept which when explored its meaning both philosophically and psychologically refers to the merging of the meaning of 
spirituality and authenticity. Purpose this article to conceptually discuss intrinsic leadership development and how the process of organizational development and transformation through intrinsic leadership.

\section{Literature Review}

\subsection{Theoritical Foundation Of Intrinsic Leadership}

The theoretical foundation used to build body knowledge intrinsic leadership is constructbased self such as self-concept, cognitive evaluation theory [54], teleonomic of self theory [55], and eudaimonistic identity theory [56], intrinsic, organizational spirituality, authentic leadership, PO Fit, positive psychology, theory of spillover of quality of work life.

\subsection{Philosophy of Holistic Leadership}

The basic principle of holistic philosophy is the existence of balance [57]. An organizational leader must be able to maintain a balance between self-interest and the integrative interests of the organization to optimize outputs for all stakeholders [57]. Leaders in a holistic perspective should integrate physical, mind, heart (feelings and emotions), and spirit [58] so that they have analytical and synthesis abilities, mind and intuition, as well as the ability to see both the inside and outside sides of the organization at various levels [57]. According to Quatro [59] leaders in a holistic perspective should have and integrate analytical, conceptual, emotional, and spiritual abilities. The integration of the four (4) key elements of the leader's domain leads to achieving organizational goals, being able to balance various interests, and being able to overcome various problems in fluctuating and predictable environment.

\subsection{Authenticity and Authentic Leadership}

a) Authenticity.

Authentic psychological meaning is as a personality or trait or character and also as an individual's identity [60]. Authentic psychological meaning related to the psychological state and human personality [59] that distinguishes between individuals with each other, which is seen from the concept of self-awareness, self referential [61], and self-determination when an individual behaves and decide on relational choices [62]. The meaning of authentic psychological is operationalized in the form of cognitive aspects (awareness), behavioral aspects, and relational aspects [63]. The main assumption of this operation is that authentic individuals have the capacity to develop more relationships meaningful and valuable both with colleagues and with others [60]. Review of psychological authentic meaning basically refers to the question "who am I" which, according to Myer [47], is related to self-concept.

b) Authentic Leadership.

Authentic leadership is defined on the basis of self-concept [31] [25] that is built through life experience [31] [5]. The authentic leadership model of Luthans \& Avolio [3] illustrates positive psychological capital and organizational contexts that have increased growth. Authentic leadership includes positive organizational behavior 
which is characterized by self efficacy, hope, optimism, and resilience which becomes the basis for psychological capital constructs [3]. Luthans \& Avolio's authentic leadership model includes core components consisting of self-awareness, positive selfcontrol, positive self-development, and positive moral perspectives that are often reflected either explicitly or implicitly [3].

Gardner propose a self-based model of the process that underlies authentic leadership [5]. Gardner's authentic leadership model positions that as a key factor contributing to the development of authentic leadership is a high degree of selfawareness of leaders towards their own values, emotions, identity, and goals. The theoretical foundation of the authentic leadership model Gardner is self-regulation which includes internalisation of regulations, balanced information processing that refers to the collection of information and interpretations about oneself that is biased, authentic behavior, and transparency relationships which means that leaders show a high level of openness, self disclosure, and trust in a close relationship [5]. This model postulates that the leader's personal history (family influence, initial challenges, education and work experience) and important events (including crises and positive important events such as promotion or division of tasks) serve as antecedents for authentic leadership. As a positive role model, authentic leaders demonstrate integrity and commitment to core ethical values and contribute to a positive organizational climate. Positive results from authentic leader-follower relations, according to Gardner include a high level of follower trust in leaders; workplace welfare; and sustainable performance [5].Walumbwa suggested that authentic leadership is a pattern of leader behavior that is based both on positive psychological capital and positive ethical climate [6]. These two foundations are used to foster higher self-awareness, internalized moral perspectives, the balance of information processes, and relational transparency when authentic leaders work with subordinates. This authentic leadership encourages positive self-development for subordinates.

While Rego et al. [18] and Freeman \& Auster [64] suggested that authentic leadership is a pattern of leader behavior that refers to and encourages both positive psychological capacity and positive ethical climate to foster self-awareness, internalizing moral perspectives, balance of the information process, and relational transparency where leaders work with subordinates, and helps develop leaders' personal values and morals, which not only emphasize quality of leader-subordinate relationship but also the character relationship between leader-subordinate.

\subsection{Spirituality}

Spirituality is one's inner life in maintaining and nurtured by meaningful work that takes place in a community context [1]. Spirituality is related to values, beliefs, attitudes, and emotions that influence, and awareness of integrating life in the process of self-transcendence to achieve the highest achievements as humans and individuals in a particular environment [34]; or also related to the meaning of life that affects psychological well-being or work welfare [65]. While Adam \& Csiernick suggested spirituality in the workplace includes positive assessment, recognition and appreciation of the inner abilities of individual members of the organization in the context of meaningful goal-oriented behavior that encourages creativity, a sense of belonging, and the fulfillment of personal growth needs [34]. Giacalone defines spirituality in the workplace with regard to organizational values that exist in cultures that prioritize employee transcendence experiences through work processes, and present a sense of being connected to others (eg empathy, ownership, trust, or honesty) by giving feelings together and happiness 
[66].The application of spirituality is manifested in sense of community and attachment[48], integration and congruence between the authentic parts of personal life and professionalism with personal values [66], as well as the ability to present oneself as a totality of all components of self in work [53].

\subsection{Self Concept}

The concept of self is a result of an individual's reflection on himself about his physical, social, and spiritual or moral [68]. Self-concept reflects and or answers the question of "who am I". Individuals find the answer "who am I" through reflection or self contemplation and comparison. The results of self-reflection are translated into identity. Reflection is basically a process of self-evaluation carried out by an individual against himself related to everything that exists in him so as to generate to respect for himself, related to his beliefs, and the source of control. Comparison is a self-assessment in the form of how oneself is compared to others. Individual self-reflection and comparison activities are highly dependent on self-orientation, sources of self-control, and social environment.

According to Deci \& Ryan self-control is an autonomy requirement, which is an intrinsic state. Self-control leads to self-regulation. Therefore, self-regulation in this case also comes from intrinsic [48]. Essentially, an individual's true self feels the welfare or happiness of his eudomania is when they come from the need for autonomy (cq intrinsic). Based on this, the discussion of self-concept leads to discussion of intrinsic.

\subsection{The Concept of Intrinsic}

The meaning of intrinsic philosophically implies the value that is owned from within itself which is the value of virtue that can not be derived again (nonderivatively) (Aristotle, Nicomachean Ethics), the values of virtue based on conscience that exists in oneself, as a source of goodness, where the value of other goodness is contained in the value of intrinsic goodness. Referring to the opinion of philosophers about the intrinsic philosophical meaning [69] [70] [71], basically the intrinsic meaning is very close to the meaning of conscience which contains understanding as a pure heartfelt and the deepest or the feeling of the heart that gets light from God. Values of kindness of conscience are values of virtue based on pure and deep feelings of heart that are sourced or received by God. Therefore, values of virtue according to conscience are virtue values that cannot be derived anymore (intrinsic according to Aristotle), values of goodness which are only possessed by individuals who have meaningful goals within themselves (intrinsic according to Kant). The intrinsic psychological meaning can be examined from the theory of self-evaluation, the theory of self-teleonomics, and the theory of self-identity [72].

\section{Result And Discussion}

\subsection{Development Of Intrinsic Leadership Concepts}

The operationalization of the concept of spirituality from intrinsic leadership is done by understanding the spirituality component. Understanding of the three components of a leader's spirituality - inner life, meaningful work activities, and caring for the community -, and also understanding the meaning of authenticity in authentic leadership using a construct approach to self-concept, intrinsic motivation, and theories about self [73] [5] [25] [33]. The concept of self 
is the result of an individual's reflection and contemplation activities about himself which are then established as his conception of his physical, social, and moral values [64]. The concept of self is also considered as the totality of the thoughts and feelings of individuals who refer to themselves as an object [74]. While self-concept according to Eipstein is a concept where an individual feels able to control himself as an experienced individual [75]. Eisptein definition of self concept emphasizes more on knowledge (as a cognitive dimension), as well as self-control and belief (as an affective dimension) where these dimensions are the desire or strong drive of individuals to carry out self-monitoring functions, and at the same time as an autonomous need which is intrinsically sourced [54]. In other words, referring to the opinion of Decy \& Ryan basically the individual needs of the presence of self-concept can be categorized as a form of intrinsic motivation.

Philosophically the intrinsic meaning is related to psychiatric which involves the inner life, where it is the meaning of the spiritual. Spirituality is define as the inner life of a person that leads to the meaningfulness of life activities carried out in social life, so intrinsic philosophically also implies the meaning of spirituality [1] [73]. Intrinsic psychological meaning according to the theory of cognitive evaluation Decy \& Ryan is associated with intrinsic leadership, that is, when the leader behavior is based on intrinsic, the leader feels the experience of interest and pleasure in conducting leadership activities, has a feeling of competence and is able to determine the direction of his work life [54]. These feelings are related to the inner life of intrinsic leaders, where inner life is one component of spirituality [1] [73]. The experience of subjective interest in intrinsic concepts is an expression of "feeling happy or enjoying the activities carried out" [76] [77]. Interest is a disposition to actively involve themselves in determining activities [78] and play a serious role in work activities [79] so as to provide feelings of pleasure, meaningfulness, and happiness in the work life of intrinsic leaders. Based on the theory of cognitive evaluation Decy \& Ryan [54], subjective experience in the intrinsic concept of a leader embodies spirituality when the activities carried out by intrinsic leaders have meaning. Activities carried out by intrinsic leaders as activities that have meaning are when the leader selects and determines his own activities carried out (self-determining) in accordance with the values of goodness that exist within himself (internal locus of causality) [80] [81] [82], and or when individuals feel competent in carrying out these activities (sense of competence) [83] [84].

The intrinsic concept according to Csikszentmihalyi's self-teleonomical theory [55] is described in the form of "autotelic," and / or self-strengthening activities. Teleonomic theory of self is part of the theory of "flow" Csikszentmihalyi, which is defined as an intrinsic state in which an individual immerses himself totally in what he does for the sake of feeling within himself [55], and is characterized by involving activity with awareness, self-control, high concentration, and self-transformation [55] [85]. Csikszentmihalyi described "flow" as an individual's affective cognitive state during performance completion based on intrinsic, full involvement in activities or activities (totality in activity / full involved) [55]. Related to the intrinsic concept of teleonomic theory of self with intrinsic leaders when the leader's activity is driven by experience flow, the leader develops autotelic personality which is characterized by the implementation of work activities based on the conscience of the leader and solely to fulfill the call of goodness and the presence of sense or meaning from within oneself (for own sake / as its own sake) as its main goal [55], involves all resources owned in totality, caution and high concentration and awareness, attention to optimal use of time, and always self monitoring and monitoring of the activities carried out [55] [85]. The embodiment of autotelic personality and full involvement of leaders based on intrinsic is the willingness of self sacrifice to achieve goals and performance; as well as generate to a feeling of sincerity that is doing work with the main goal not based on external goals themselves [55]. Self sacrifice and self sincerity according to 
the spiritual dimension are important determinants of effective leadership [33].Subjective experience of "flow" based on intrinsic leaders describes affective cognitive state during completion of performance that is based on intrinsic, and total involvement in the activities carried out. Activities carried out are in a state of "flow" when these activities are freely chosen. This shows that intrinsic leaders have confidence that they can determine what they want to do and determine what they want to achieve (self determination) [54] [55] [86]. Therefore it can be concluded that the determinant factor of intrinsic leader behavior is the internal locus of causality. Thus intrinsic leaders are leaders who have internal locus of control, that is, leaders who have individual belief in their ability to control what is done and what is expected and obtained [87].

Another perspective of intrinsic concepts is rooted in the study of self-identity [72]. The concept of self-identity is a psychosocial state that refers to goals, values, and beliefs which are the main points of an individual's self-definition, which provide direction and meaning of activities to individuals [61]. Self-identity is a personal expression [88] [25] that reflects an individual's core beliefs [88]. Philosophically, personal expression has almost the same meaning as Aristotle's eudaimonia concept [56]. Eudaimonia is an ethical theory that directs individuals to recognize and have an awareness of their own abilities [69] [89]; as an activity that expresses morality, in which morality is understood as a perfection or as the best that exists in humans [90]; reflect the life of an individual who actively expresses the character or values that exelence in the life of the individual [25]; as a subjective state of an individual's desire to do something that is considered valuable or has meaning [89]; and is a subjective state related to actions to fulfill personal potential [72]. Meanwhile, according to Waterman personal expressive feelings indicate activities that are based on the values of self-realization. Related to this, self-realization is an individual's personal expression of the individual's goals, values, and personal beliefs that show self-definition, as well as giving direction and meaning to the behavior or action of the individual [72].

Intrinsic leader personal expression that generate to eudaemonic well-being occurs when intrinsik leader feels intensive involvement with his actions and life [72], feels the peak of his experience of interest, motivation, and pleasure during his activities, and really enjoys working activities that are in accordance with life values owned [25] [72]. Therefore, eudaemonic wellbeing is a reflection of self-realization, personal growth and self-expression, and the realization of the true nature of leaders [25]. Eudaemoni as a reflection of self-realization in all leader's life spaces [91] [92] [93] is achieved when leader have a feeling of self-acceptance, have the ability to manage as a whole effective life and the environment around them (environmental mastery), have a clear purpose in life (purpose in life), develop positive relationships with other individuals (positive relationships), make personal growth (personal growth), and determine for themselves what to do or have self-autonomy (self determination) [92]. From the concept of self-realization from an eudaemonia perspective, intrinsic leaders have a feeling of the meaning and purpose of their lives, which according to Klenke is an indicator of the spiritual dimension [33].

The development of an intrinsic leadership model as illustrated in Figure 1 focuses on authentic elements and spirituality and the process by which intrinsic leadership contributes to the eudaemonic well-being of leaders and followers. Intrinsic as a motivational and dispositional variable has major implications for the leadership process in influencing the eudaemonic wellbeing of not only the leader himself but also having an impact on eudaemonic well-being and the intrinsic concept of his followers. The intrinsic leadership model describes that eudaemonic well-being occurs when leaders and followers are honest with themselves and are actively involved and totality in realizing their true potential, which is reflected by a high level of self- 
awareness, high self-regulation, authentic behavior, and a level of sincerity, a level of sacrifice self, feelings of meaning and high goals, and have a source of internal control.

Based on a review and basic theoretical models of intrinsic leadership, the preposition of intrinsic leadership is formulated as (1) a pattern of leader behavior that refers to and encourages both positive psychological capacity and positive ethical climate, (2) which shows a leader's self-awareness of one's own understanding and knowledge of self, how other people see themselves, and understand how their impact on others; (3) which is characterized by a high level of self-regulation that is reflected by an internalized moral perspective, and balanced information processing about oneself; (4) that establishes transparent and close relations with all stakeholders; (5) and have spiritual values expressed with sincerity, self-sacrifice, internal locus of control, and feelings of meaning and purpose, so that they can contribute to the eudaemonic well being of leaders and followers, so that they are finally able to improve the behavior of sustainable performance.

Intrinsic leadership development as a new construct of leadership whose development is based on a holistic philosophy of leadership, covers all aspects of the leader as a human being where in the previous construct or leadership theory only one or several aspects of the leader as a human being [94]. Intrinsic leadership as a new leadership construct is expected to be able to have an impacful effect on the development of positive organizational capacity so as to be able to bring the organization to sustainable performance. This is because a leader is intrinsic in playing his role and functions by empowering his psychological, cognitive, and spiritual capacities with spiritual as the core of the direction. Intrinsic leaders are expected to be able to resilience in an environment that is unpredictable, authenticity, self-sacrifice, self-confidence, and that whatever is done well has meaning and purpose.

Relying on the opinion of Corley \& Gioia which states that theoretical contribution refers to the ability of a study to provide original ideas into a phenomenon to increase knowledge, and is considered to have utility for several purposes [95]. Originality is the development of progress and / or expansion of an existing knowledge, concept, or theory [95]; or a potential contribution to a revelatory [96]. Utility concerns whether research contributes to the improvement of research practices that have been carried out by experts (scientific utility) or contributes to the improvement of managerial practices for organizational practitioners (practical utility). Intrinsic leadership as a new construct of leadership is holistic leadership that integrates spiritual aspects in the cognitive, affective, and conative aspects contained in the concept of authentic leadership which is expected to improve organizational performance. So that if it is related to the aspect of originality, this study seeks to prove the importance of spirituality in authentic leadership theory. Or in other words, intrinsic leadership is a leader who reflects the spiritual, cognitive, affective, and conative aspects of the leadership process. Thus the development of intrinsic leadership expands or is incremental to previous leadership theories, namely authentic leadership. Intrinsic leadership is also considered an intermediate theory research [97] because it proposes a relationship between new constructs (spirituality) and existing constructs (authentic leadership).

\subsection{Organizational Development Through Intrinsic Leadership}

The spirituality that is applied by intrinsic leaders generate to a feeling of work activities carried out that has meaning, indicates a positive assessment, recognition, and respect for the inner life of leader. where the meaning of the behavior is certainly oriented towards the ultimate goals of intrinsic leader so that it encourages creativity, a sense of belonging, and meeting personal needs. The meaning of work activities is felt by intrinsic leaders when they integrate spiritual values in work settings and or completion of tasks and work. Thus in the context of spiritual-based intrinsic leadership, leaders apply their spiritual values in the workplace to 
influence organizational behavior, interactions, and outcomes [35]. The application of intrinsic leaders' spiritual values in the workplace has consequences for organizational outcomes [35]. The relationship between the application of intrinsic leaders' spiritual values and their consequences in this regard can be explained using the concept of person-organization fit (P-O fit) [35], theories of spillover of quality of work life [35], and organizational climate [72]..

The concept of person-organization fit (P-O fit) is a perceptual construct that refers to the congruence between values and personal goals with the values and goals of the organization [98]. Associated with the spiritual dimension of intrinsic leadership, the concept of the congruence of the spiritual values of intrinsic leaders with organizational spiritual values can be explained using the theory of spillover of quality of work life [35]. The theory of spillover of quality of work life, generally consists of two types, vertical spillover and horizontal spillover. In vertical spillover, satisfaction with one dimension of the quality of one's work life (for example satisfaction of happiness or psychological well-being) affects the satisfaction of one's work life as a whole. While in horizontal spillover, satisfaction in one domain of one's work life affects the satisfaction of other domains that are around it. Therefore, intrinsic leader satisfaction with his personal spiritual life spread to personal work life satisfaction and influences work life satisfaction in the organization [35].

Positive horizontal spillover of the intrinsic leader's spiritual values on work-related problems creates a positive organizational spiritual climate [35]. By using Lewin's basic framework in which behavior is a function of the environment and personal, intrinsic leaders as agents of organizational systems (environment) can create a work climate for organizational members (subordinates) who act as subjects of organizational systems (environment ). Intrinsic leader spiritual values that are manifested in behavior affect the subject (subordinate) and organizational system so as to encourage a positive organizational climate [35]. A positive organizational climate leads to organizational outputs such as improved organizational performance, and job satisfaction [99].

Intrinsic leadership is assumed to function as a positive role model that demonstrates the integrity and commitment of core ethical values and is able to contribute to a positive organizational climate. The leader-follower relationship in intrinsic leadership is hypothesized to be able to show a high level of follower trust in leaders, workplace well-being, high job satisfaction, and ongoing performance. Therefore intrinsic leadership is assumed to be able to reach a deeper level of meaning of the relationship between leader and follower, and this happens when the leader and follower are involved with each other in such a way that can increase motivation and higher morality.

\section{Conclusion}

Intrinsic leadership can be viewed as constructs that are in the initial concept stage of development. The development of new concepts in this study refers to the opinion of Cooper that before designing a new concept development strategy, one must carefully consider four (4) important issues: (1) defining constructs and identifying the main dimensions of the construct that will be developed; (2) determine the construct validity; (3) identify the results and or outputs of relevant constructs; and (4) ensuring whether the construct can be applied. Intrinsic leadership construct is defined as a pattern of behavior that leaders are driven by a positive psychological and positive ethics are built on the basis of a causal relationship between the dimensions of cognitive, affective, conative and as its main core is spiritual dimension [100]. At this stage, it 
is important research on several fronts is necessary to establish the validity of intrinsic leadership before it should be widely applied as a model of organizational development to foster systemic change and transformation. Organizational outcomes (e.g. commitment, organizational performance, positive organizational climate) hypothesized to be affected by intrinsic leadership also need to be validated for intrinsic leadership construct. Finally, the conceptual distinction between intrinsic leadership theory variables and other leadership theories and constructs needs to be refined. From originality, the development of new intrinsic leadership constructs can contribute theoretical contributions as incremental knowledge to the previous body of knowledge of leadership theory, by combining all aspects of the leader as a human being (spiritual, cognitive, affective, and conative). From utility, intrinsic leadership is expected to be able to make a practical contribution to achieving positive organizational output and sustainable performance, especially for simple organizations.

\section{Acknowledgments}

We give grateful acknowledgement to Mr. Ratno, Mrs. Wiwiek Mr. Sujadi for their most critical and constructive comments on developing the novelty of this concept in preparing my dissertation. And we are most appreciative of suggestions offered of a number anonymous reviewers of this article.

\section{References}

[1] Ashmos D.P., \& Duchon, D: Spirituality at Work. Journal of Management Inquiry. 9, pp. 134 - 146 (2000)

[2] Wooley, Lydia; Caza, Arran; \& Levy, Lester: Authentic Leadership and Follower Development: Psychological Capital, Positive Work Climate, and Gender. Journal of Leadership \& Organizational Studies, 18(4) pp. $438-448$ (2011)

[3] Luthans, F., \& Avolio, B: Authentic leadership: A positive development approach. In K. Cameron, J. Dutton, \& R. Quinn (Eds.), Positive organizational scholarship (pp 241258).San Francisco: BerrettKoehler (2003)

[4\} Avolio, B. J., Gardner, W. L., Walumbwa, F. O., Luthans, F., \& May, D. R: Unlocking the mask: A look at the process by which authentic leaders impact follower attitudes and behavior. The Leadership Quarterly, 15 pp. 801-823 (2004)

[5] Gardner, W. L., Avolio, B. J., Luthans, F., May, D. R., \& Walumbwa, F. O : "Can you see the real me?" A self-based model of authentic leader and follower development. The Leadership Quarterly, 16, pp. 343-372 (2005)

[6] Walumbwa, Fred O., Avolio, Bruce J., Gardner, William L., Wernsing, Tara S., \& Peterson, Suzanne J: Leadership: Development and Validation of a Theory-Based Measure. Journal of Management, Vol. 34(1) pp. 89-126 doi: 10.1177/0149206307308913 (2008)

[7] Avolio, B. J., \& Luthans, F: High impact leader: Moments matter in accelerating authentic leadership. New York, NY: McGraw-Hill (2006)

[8] Kiersch, C.E., \& Byrne, Z.S: Is Being Authentic Being Fair? Multilevel Examination of Authentic Leadership, Justice, and Employee Outcomes. Journal of Leadership \& Organizational Studies, 1 12 doi: $10.1177 / 1548051815570035$ (2015)

[9] Jensen, Susan M, \& Luthans, Fred: Entrepreneurs as Authentic Leaders: Impact on Employees's Attitudes. Leadershhip \& Organization Develepoment Journal, Vol. 27 Iss 8 pp. 646-666 (2006) 
[10] Peus, C., Wesche, J.S., Streicher, B., Braun, S., \& Frey, D: WeschAuthentic Leadership: An Empirical Test of Its Antecedents, Consequences, and Mediating Mechanisms. Journal of Business Ethics, Vol. 107 Iss. 3 pp. 331 - 348 (2011)

[11] Giallonardo, L. M., Wong, C. A., \& Iwasiw, C. L: Authentic leadership of preceptors: Predictor of new graduate nurses' work engagement and job satisfaction. Journal of Nursing Management, 18, 993-1003 (2010)

[12] Toor, S., \& Ofori, G: Authenticity and its influence on psychological well-being and contingent selfesteem of leaders in Singapore construction sector. Construction Management and Economics, 27, pp. 299-313 (2009)

[13] Wong, C. A., \& Cummings, G. G: The influence of authentic leadership behaviors on trust and work outcomes of health care staff. Journal of Leadership Studies, 3(2), pp. 6-23 (2009)

[14] Clapp-Smith, R., Vogelgesang, G. R., \& Avey, J. B: Authentic leadership and positive psychological capital: The mediating role of trust at the group level of analysis. Journal of Leadership and Organizational Studies, 15, 227240.Cohen, R.J., \& Swerdlik, M.E. 2005. Psychological Testing and Assessment: An Introduction To Tests And Measurement. New York: McGrawHill, Inc (2009)

[15] Hmieleski, K.M., Cole, M.S., \& Baron, R.A: Shared Authentic Leadership and New Venture Performance. Journal of Management, Vol. 38 (5) pp. 1476-1499 doi: 10.1177/0149206311415419 (2012)

[16] Leroy, H., Anseel, F., Gardner, W,L., \& Sels, L: Authentic Leadership, Authentic Followership, Basic Need Satisfaction, and Work Role Performance: A Cross-Level Study. Journal of Management, Vol. 20 (10) pp. 1-21 (2012)

[17] Erkutlu, H. \& Chafra, J: Effects of trust and psychological contract violation on authentic leadership and organizational deviance. Management Research Review, Vol. 36 Iss 9 pp. 828 - 848 (2013)

[18] Rego, A., Sousa, F., Marques, C., \& Cunha, M.P: Authentic leadership promoting employees' psychological capital and creativity. Journal of Business Research, 65, pp.429-437 (2012)

[19] Peterson, S. J.,Walumbwa, F.O., Avolio, B. J., \& Hannah, Sean T: The relationship between authentic leadership and follower job performance: The mediating role of follower positivity in extreme contexts. The Leadership Quarterly, Vol. 23, Iss. 3 pp. 502-516 (2012)

[20] Zhu, W., Avolio, B.J., Riggio, R.E., Sosik, J.J: The effect of authentic transformational leadership on follower and group ethics. The Leadership Quarterly, 22(5) pp. 801-817 (2011)

[21] Walumbwa, Fred O., Wang, Peng, Wang, Hui, Schaubroeck, John, \& Avolio Bruce J: Psychological processes linking authentic leadership to follower behaviors. The Leadership Quarterly, 21, pp. 901-914 (2010)

[22] Wong, C. A., Spence Laschinger, H. K., \& Cummings, G. G: Authentic leadership and nurses' voice behaviour and perceptions of care quality. Journal of Nursing Management, 18, pp. 889-900 (2010)

[23] Avolio, B. J., Luthans, F., \& Walumbwa, F. O: Authentic leadership: Theory-building for veritable sustained performance. Working paper. Gallup Leadership Institute, University of Nebraska-Lincoln (in Gardner, W.L., Cogliser, C.C., Davis, K.M., \& Dickens M.P. 2011. Authentic leadership: A review of the literature and research agenda. The Leadership Quarterly, 22, pp.1120-1145 (2004)

[24] Gardner, W. L., Avolio, B. J., Luthans, F., May, D. R., \& Walumbwa, F. O: "Can you see the real me?" A self-based model of authentic leader and follower development. The Leadership Quarterly, 16, pp. 343-372 (2005)

[25] Ilies, R., Morgeson, F. P., \& Nahrgang, J. D: Authentic leadership and eudaemonic well-being: Understanding leader-follower outcomes. The Leadership Quarterly, 16, 373-394 (2005)

[26] Harvey, P., Martinko, M. J., \& Gardner, W. L: Promoting authentic behavior in organizations: An attributional perspective. Journal of Leadership and Organizational Studies, 12(3), 1-11 (2006)

[27] Caza, A., Bagozzi, R.P., Wooley, L., Levy, L., \& Caza, B.B: Psychological capital and authentic leadership: Measurement, gender, and cultural extension. Asia-Pacific Journal of Business Administration, Vol. 2 (1), pp. 53-70 doi 10.1108/17574321011028972 (2013)

[28] Liu, H., Cutcher, L., \& Grant, D: Doing Authenticity: The Gendered Construction of Authentic Leadership. Gender, Work, and Organization, 22 (3), pp. 237 - 255 (2015) 
[29] Regan, Sandra, Laschinger, Heather K.S., \& Wong Carol A: The influence of empowerment, authentic leadership, and professional practice environments on nurses' perceived interprofessional collaboration. Journal of Nursing Management, 24, E54-E61 doi: 10.1111/jonm.12288 (2016)

[30] Steffens, Niklas K. Mols Frank, Haslam S. Alexander, \& Okimoto, T.G: True to what we stand for: Championing collective interests as a path to authentic leadership. Article in Press. The Leadership Quarterly, doi: 10.1016

[31] Shamir, Boas \& Eilam, Galid. 2005. What's your story? A life-stories approach to authentic leadership development. The Leadership Quarterly, 16, pp. 395-417 (2016)

[32] Klenke, K: The internal theatre of the authentic leader: Toward an integrated model of authentic leadership. UNL Gallup Leadership Summitt (2004)

[33] Klenke, K: The internal theatre of the authentic leader: Integrating cognitive, affective,conative and spiritual facets of authentic leadership. In W. Gardner, B. Avolio, \& F.Walumba (Eds.), Authentic leadership theory and practice: Origins, effects and development: Vol. 3. Monographs in Leadership and Management (pp. 155-182). NewYork: Elsevier (2005)

[34] Krishnakumar, S., \& Neck, C.P: The "What, Why, and How" of Spirituality in the Workplace. Journal of Managerial Psychology, 17 (3), pp. 153 - 164 (2002)

[35] Kolodinsky, RW; Giacalone, RA; \& Jurkiewicz, CL: Workplace Values and Outcomes: Exploring Personal, Organizational and Interactive Workplace Spirituality, Journal of Business Ethics, pp 81:465-480 DOI 10.1007/s10551-007-9507-0 (2008)

[36] Freshman, B: An Exploratory Analysis of Definition and Application of Spirituality in the Workplace. Journal of Organizational Change Management, 12 (4), pp. 318 - 327 (1999)

[37] Wagner-Marsh, F., \& Lonely, J: The Fourth Wave: The Spirituality based Firm. Journal of Organizational Change Management, 12 (4), pp. 292 - 301 (1999)

[38] Burack, E.H: Spirituality in the Workplace. Journal of Organizational Change Management, 12 (4), pp. $280-291$ (1999)

[39] DelBeq, L.A: Christian Spirituality and Contemporary Business Leadership. Journal of Organizational Change Management, 12 (4), pp. 345 - 349 (1999)

[40] Leigh, P: The New Spirit of Work. Training and Development, 51 (3), pp. 26 - 34 (1997)

[41] Altaf, A., \& Awan, M. A: Moderating Effect of Workplace Spirituality on the Relationship of Job Overload and Job Satisfaction. Journal of Business Ethics, 104, pp.93-99 doi 10.1007/s10551-0110891-0 (2011)

[42] Kazemipour, F., Mohamad Amin, S., \& Pourseidi, B: Relationship between Workplace Spirituality and Organizational Citizenship Behavior among Nurses through Mediation of Affective Organizational Commitment. Journal of Nursing Scholarship, 44 (3), pp. 302 - 310 (2012)

[43] Jelil Ladebo, o., Jacob Olaoye, O., \& Oyekale Adamu, O: Extension Personnel's Self-Esteem and Workplace Relationships: Implications for Job Satisfaction and Affective Organizational Commitment Foci. The Journal of Agricultural Education and Expansion, 14 (3), pp. 249 - 263 (2008)

[44] Sass, J: 'Characterizing Organization Spirituality: An Organizational Communication Culture Approach', Communication Studies 51(3), 195-217 (2000)

[45] Case, P., \& Gosling, J: The Spiritual Organization: Critical Reflections on the Instrumentality of Workplace Spirituality. Journal of Management Spirituality \& Religion, 7 (4), pp. 257 - 282 (2010)

[46] Avolio, B., \& Gardner, W: Authentic leadership development: Getting to the root of positive forms of leadership. The Leadership Quarterly, 16 Iss.3 pp. 315-338 (2005)

[47] Myers, David G: Social psychology. $10^{\text {th }}$ ed.. New York: McGraw-Hill Higher Education. ISBN 0073370665 (2009)

[48] Deci, E. L., \& Ryan, R. M: The "What" and "Why" of Goal Pursuits: Human Needs and the SelfDetermination of Behavior. Psychological Inquiry, Vol. 11, No. 4, pp. 227-268 (2000)

[49] Driver, M: From Empty Speech to Full Speech? Reconceptualizing Spirituality in Organizations Based on a Psychoanalytically-Grounded Understanding of the Self. Human Relations, 58(9), pp.1091-1110 (2005)

[50] Neal, J: Work as Service to the Divine. American Behavioral Scientist, 43(8), pp.1316-1333 (2000) 
[51] Kurth, K: Spiritually Renewing Ourselves at Work. Finding Meaning through Service. In R. A. Giacalone and C. L Jurkiewicz (eds.Handbook of Workplace Spirituality and organizational Performance (M. E. Sharpe, Armonk, New York), pp. 447-460 (2003)

[52] Fry, L. W: Spiritual leadership: State-of-the-art and future directions for theory, research, and practice. In J. Biberman \& Tishman, L. (Eds.), Spirituality in business: Theory, practice, and future direction (pp. 106-124). New York: Palgrave (2008)

[53] Gotsis, G. \& Kortezi, Z: Philosophical Foundations of Workplace Spirituality: A Critical Approach. Journal of Business Ethics, 78, pp. 575-600 doi 10.1007/s10551-007-9369-5 (2008)

[54] Deci, E. L., \&Ryan, R. M: Intrinsic motivation and self-determination in human behavior. NewYork:Plenum (1985)

[55] Csikszentmihalyi, M: Flow: The psychology of optimal experience. New York: Harper \& Row (1990)

[56] Waterman, A. S: Personal expressiveness: Philosophical and psychological foundations. Journal of Mind and Behavior, 11, pp. 47-74 (1990)

[57] Carlopio, J: Holism: A Philosophy of Organizational Leadersih for the Future. The Leadership Quarterly, Vol. 5 Iss 3-4 pp. 297-307 (1994)

[58] Moxley, R.S: Leadership \& Spirit Breathing New Vitality and Energy into Individuals and Organizations. San Francisco: Jossey-Bass Inc. (2000)

[59] Quatro, Scott A., Waldman, David A., \& Galvin, Benjamin M: Developing holistic leaders: four domain for leadership development and practice. Human Resourch Management Review, 17, pp. 427 -441 (2007)

[60] Novicevic, Milorad M., Harvey, Michael G., Buckley, M. Ronald, Brown Jo Ann, \& Evans, Randy: Authentic Leadership: A Historical Perspective. Journal of Leadership and Organizational Studies, Vol. 13 (1), pp. 64 - 76 (2006)

[61] Erickson, R: The importance of authenticity for self and society, Symbolic Interaction 18(2) pp. 121144 (1995)

[62] Kernis, M: Optimal self-esteem and authenticity: Separating fantasy from reality, Psychological Inquiry, 14(1), pp. 83-89 (2003)

[63] Goldman, B.M. \& Kernis, M.H: The Role of Authenticity in Healthy Psychological Functioning and Subjective Well-Being, Annuals of the American Psychotherapy Association, 5, pp. 18-20 (2002)

[64] Freeman, R. Edward, \& Auster, Ellen R: Values, Authenticity, and Responsible Leadership. Journal of Business Ethics, 98, pp. 15-23; doi 10.1007/s10551-011-1022-7 (2011)

[65] DeKlerk, J.J: Spirituality, Meaning in Life, and Work Wellness: A Research Agenda. International Journal of Organizational Analysis, Vol. 13 Issue: 1, pp.64-68, https://doi.org/10.1108/eb028998 (2005)

[66] Giacalone, R. A., \& Jurkiewicz, C. L: Toward a science of workplace spirituality. In R. A. Giacalone \& C. L. Jurkiewicz (Eds.), Handbook of workplace spirituality and organizational performance (pp. 3-28). Armonk, NY: M. E. Sharpe (2003)

[67] Kurth, K: Spiritually Renewing Ourselves at Work. Finding Meaning through Service. In R. A. Giacalone and C. L Jurkiewicz (eds.Handbook of Workplace Spirituality and organizational Performance (M. E. Sharpe, Armonk, New York), pp. 447-460 (2003)

[68] Gecas, V: The Self-Concept. Annual Review of Sociology. Vol. 8 pp. 1-33 (1982)

[69] Aristotle: Nichomachean ethics (T. Irwin, Trans.). Indianapolis, IN: Hackett (1985)

[70] Brentano, Franz, (originally published in 1889): The Origin of Our Knowledge of Right and Wrong, London: Routledge and Kegan Paul (1969)

[71] Kant, I: Grounding for the Metaphysics of Morals. Indianapolis: Hackett Publishing Co (1981)

[72] Waterman, A.S., Schwartz, S. J., Goldbacher, E., Green, H., Miller, C., \& Philip, S: Predicting the Subjective Experience of Intrinsic Motivation: The Roles of Self-Determination, the Balance of Challenges and Skills, and Self-Realization Values. Personality and Social Psychology Bulletin, Vol. 29 No. 11 pp. 1147 - 1158, doi: 10.1177/0146167203256907 (2003)

[73] Duchon, D., \& Plowman, D.A: Nurturing the Spirit at Work: Impact on Work Unit Performance. The Leadership Quarterly, 16:5, pp. 807 - 833 (2005)

[74] Rosenberg, M: Conceiving the Self. NY: Basic (19790) 
[75] Epstein, S: The self-concept revisited a theory of a theory. American Psychologist. 28:404- 414 (1973)

[76] Deci, E. L: The relations of interest to the motivation of behavior: A self-determination theory perspective. In K.A. Renninger, S. Hidi, \& A. Krapp (Eds.), The role of interest in learning and development (pp. 43-70). Hillsdale, NJ: Lawrence Erlbaum (1992)

[77] Sansone, C., \& Harackiewicz, J. M: "I don't feel like it": The function of interest in self-regulation. In L. L. Martin \& A. Tesser (Eds.), Striving and feeling: Interactions among goals, affect, and selfregulation (pp. 203-228). Mahwah, NJ: Lawrence Erlbaum (1996)

[78] Krapp, A., Hidi, S., \& Renninger, K: AInterest, learning, and development. In K. A. Renninger, S. Hidi, \& A. Krapp (Eds.), The role of interest in learning and development (pp. 3-26). Hillsdale, NJ: Lawrence Erlbaum. (1992).

[79] Rathunde, K: The experience of interest: A theoretical and empirical look atits role in adolescent talent development. In M.L. Maehr \&P. R. Pintrich (Eds.), Advances in motivation and achievement: Motivation and adolescent development.Greenwich,CT:JAI (1993).

[80] Deci, E. L., \& Ryan, R. M: The support of autonomy and the control of behavior. Journal of Personality and Social Psychology, 53, pp. 1024-1037 (1987)

[81] Ryan, R. M: Agency and organization: Intrinsic motivation, autonomy and the self in psychological development. In J. Jacobs (Ed.), Nebraska symposium on motivation: Developmental Perspectives on Motivation, Vol. 40, pp. 1-56 (1993)

[82] Zuckerman, M., Porac, J., Lathin, D., Smith, R., \& Deci, E. L: On the importance of self-determination for intrinsically motivated behavior. Personality and Social Psychology Bulletin, 4, pp. 443-446 (1978)

[83] Harackiewicz, J. M., \& Larsen, J. R., Jr: Managing motivation:The impact of supervisor feedback on subordinate task interest. Journal of Personality and Social Psychology, 51, 547-556 (1986)

[84] Reeve, J., \& Deci, E. L: Elements of the competitive situation that affect intrinsic motivation. Personality and Social Psychology Bulletin, 22, 24-33 (1992)

[85] Nakamura, J. \& Csikszentmihalyi, M: Flow theory and research. In Handbook of positive psychology. C. R. Snyder, Shane J. Lopez. Oxford University Press (2009)

[86] Graef, R., Csikszentmihalyi, M., \& Gianinno, SM: Measuring intrinsic motivation in everyday life. Journal Leisure Studies, Vol. 2 Iss. 2, pp. 155 - 168 (1983)

[87] Rotter, J.B: Generalized Expentancies for Internal Versus External Locus of Control of Reinforcement. Psychological Monographs, 80 Whole N0.69 (1990)

[88] Waterman, A. S: Identity as an aspect of optimal psychological functioning. In G. R. Adams, T. Gullotta, \&R. Montemayor (Eds.), Advances in adolescent development: Vol. 4. Identity formation during adolescence (pp. 50-72). Newbury Park, CA: Sage (1992)

[89] Norton, D. L: Personal destinies.Princeton, NJ: Princeton University Press (1976)

[90] Ackrill, J. L: Aristotle's ethics. London: Faber and Faber. In Waterman, A.S., Schwartz, S. J., Goldbacher, E., Green, H., Miller, C., \& Philip, S. 2003. Predicting the Subjective Experience of Intrinsic Motivation: The Roles of Self-Determination, the Balance of Challenges and Skills, and Self-Realization Values. Personality and Social Psychology Bulletin, Vol. 29 No. 11 pp.1147-1158, doi: 10.1177/0146167203256907 (1973)

[91] Keyes, C. L. M., Shmotkin, D., \& Ryff, C. D: Optimizing well-being: The empirical encounter of two traditions. Journal of Personality and Social Psychology, 82, 1007-1022 (2002)

[92] Ryff, C. D., \& Keyes, C. L. M: The structure of psychological well-being revisited. Journal of Personality and Social Psychology, 69, 719-727 (1995).

[93] Ryff, C. D., \& Singer, B: The contours of positive human health. Psychological Inquiry, 9, 1-28 (1998)

[94] Fry, L.W: Toward A Theory of Spiritual Leadership. The Quarterly Leadership. 14, 6 pp. 693 - 727 (2003)

[95] Corley Kevin G., \& Gioia, Dennis, A: Building Theory about Theory Building: What Constitutes a Theoretical Contribution? Academy of Management Review, Vol. 36, (1), pp. 12-32 (2011)

[96] Whetten, D. A: What constitutes a theoretical contribution? Academy of Management Review, 14, pp. 490-495 (1989) 
[97] Edmonson, A.C., \& McManus, S.E: Methodological Fit in Management Field Research. Academy of Management Review, Vol. 32, No. 4, pp. 1155-1179 (2007)

[98] Caplan, R. D. and Harrison. R. V: Person-Environment Fit Theory: Some History, Recent Developments, and Future Directions. Journal of Social, Issues 49, pp. 253-276 (1993)

[99] Luthans, F., Avolio, B.J., Avey, J.B., \& Norman, Steven M: Positive Psychological Capital: Measurement and Relationship with Performance and Satisfaction. Personnel Psychology 60, pp. 541-572 (2007)

[100] Cooper, C.D., Scandura, T.A., \& Schriesheim, C.A: Looking forward but learning from our past: Potential challenges to developing authentic leadership theory and authentic leaders. The Leadership Quarterly, 16 pp 475-493 (2005) 